\title{
Developing and validating the Japanese version of the situational Awe cale (SAS-J)
}

\author{
Kazuki Sawada ${ }^{1,2}\left(\mathbb{1} \cdot\right.$ Michio Nomura $^{1}$
}

Accepted: 27 January 2022

(c) The Author(s) 2022

\begin{abstract}
The experience of awe, an emotional response to vast stimuli overwhelming ones' current mental structure, has often been measured using a questionnaire method. The purpose of the present study was to develop and validate the Japanese version of the Situational Awe Scale (SAS), which is a useful tool for measuring awe experiences from the perspective of the discriminability between positive- and threat-awe. The present study investigated the factor structure and validity of the Japanese version of the SAS (SAS-J) using awe-inducing video clips, through three online surveys $(N=1034$; mean age $=38.74, S D=10.95$, range $=18-75)$. Results revealed that the SAS-J consisted of the same four factors as the original SAS (i.e., connection, oppression, chills, and diminished self) and had the convergent, criterion, and discriminative validity in measuring both positive- and threat-awe experiences. Additionally, results showed that the SAS-J could distinguish between positive- and threat-awe experiences. These results suggested that the SAS-J could measure both positive- and threat-awe experiences with validity. This study would make a methodological contribution to awe research.
\end{abstract}

Keywords Awe $\cdot$ Threat $\cdot$ Scale $\cdot$ Validity $\cdot$ Japanese

\section{Developing and validating of the Japanese version of the Situational Awe Scale (SAS-J)}

Awe, an emotional response to vast stimuli that transcend ones' current schema (Keltner \& Haidt, 2003), has been widely researched from various social, cognitive, clinical, and physiological psychology perspectives. Awe increases feelings of being connected to others, community, and oneness (Bai et al., 2017; Nelson-Coffey et al., 2019; Shiota et al., 2007; Stellar et al., 2017; van Cappellen \& Saroglou, 2012), enhances feelings of oppression (Gordon et al., 2017), involves psychophysiological responses (Chirico et al., 2017; Quesnel \& Riecke, 2018; Schurtz et al., 2012), and inspires a sense of diminished self (Bai et al., 2017, 2021; Gordon et al., 2017; Piff et al., 2015; Shiota et al.,

Kazuki Sawada

sawada.kazuki.74z@st.kyoto-u.ac.jp

Michio Nomura

nomura.michio.8c@kyoto-u.ac.jp

1 Graduate School of Education, Kyoto University, Kyoto, Japan

2 Japan Society for the Promotion Science, Tokyo, Japan
2007). Previous studies have often utilized questionnaire methods to briefly and comprehensively assess such psychological changes after awe experiences (Gabriel et al., 2020; Graziosi \& Yaden, 2021; Krogh-Jespersen et al., 2020; Price et al., 2021). As previous research has reported on the culturally specified characteristics of awe experiences in Japan (Nakayama et al., 2020; Nomura et al. 2022), developing a Japanese version of a well-validated measure of a temporary awe experience would make a methodological contribution to awe research in Japan and improve cultural comparisons between awe experiences in Japan and Western countries.

To the best of our knowledge, there are two measures of awe experiences: the Situational Awe Scale (SAS; Krenzer et al., 2020), a scale composed of four factors (connection, oppression, chills, and diminished self), and the Awe Experience Scale (AWE-S; Yaden et al., 2019), a scale composed of six factors (altered time perception, self-diminishment, connectedness, perceived vastness, physical sensations, and need for accommodation). One of the biggest differences between the SAS and AWE-S is the discriminability between the positive- and threat-awe experiences. Although it has been demonstrated that the SAS can differentiate between two types of awe, it is unclear whether the AWE-S can do 
the same. Awe is classified into positive-awe and threatawe. Positive awe is often induced by beautiful landscapes and great people, and threat-awe is often induced by natural disasters and terror attacks (Gordon et al., 2017). Previous research has also demonstrated that positive- and threat-awe were distinct form the perspectives of personality, behavior, and physiological response (Gordon et al., 2017; Guan et al., 2019; Nakayama et al., 2020; Sawada \& Nomura, 2020), suggesting that they are an important part of research on awe. More importantly, threat-awe is associated with cultural differences in awe experiences; for example, while dispositional positive- and threat-awe are independent among North Americans, both dispositions are positively related among Japanese (Nakayama et al., 2020). Although awe is manly regarded as a positive emotion in Western cultures (Shiota et al., 2006), Japanese people also tend to recall positive- and threat-awe experiences equally when asked to recall awe experiences (Nomura et al. 2022). These previous studies have also demonstrated that threat appraisals are associated with the culturally specific characteristics of awe experiences in Japan, suggesting that threat-awe is also an important topic for investigating cultural differences in awe experiences. Hence, developing a Japanese scale that can distinguish positive- and threat-awe experiences would expand our knowledge regarding threat-awe experiences in Japan and cultural differences in awe experiences. Previous research that helped develop the SAS demonstrated that positive awe experiences enhanced greater feelings of connection than threat-awe experiences, while threat-awe experiences induced greater feelings of oppression than positiveawe experiences (Krenzer et al., 2020), suggesting that the SAS can distinguish between positive- and threat-awe experiences. Considering the significance of the discriminability between positive- and threat-awe experiences, in the current study, we aimed to develop and validate a Japanese version of the Situational Awe Scale (SAS-J) according to original research (Krenzer et al., 2020).

The original SAS is associated with various variables: small self, dispositional awe, and well-being (Krenzer et al., 2020). Consistent with research suggesting that small self and dispositional awe are positively associated not only each other (Piff et al., 2015), but also with the feeling of connectedness and self-reported psychophysiological responses (Yaden et al. 2019), connection, chills, and diminished self are positively associated with small self and dispositional awe. Additionally, many previous studies have demonstrated that positive-awe experiences increased subjective wellbeing (Anderson et al., 2018; Bai et al., 2021; Krause \& Hayward, 2015; Rudd et al., 2012; Sturm et al., 2020; Zhao et al., 2019). In particular, feelings of awe positively predict life satisfaction through increased senses of connection to others (Krause \& Hayward, 2015). In line with previous research, feelings of connection after awe-experiences are positively associated with the search for meaning in life, presence of meaning in life, daily gratitude, subjective happiness, and life satisfaction (Krenzer et al., 2020). In contrast, correlations between other SAS subscales (i.e., oppression, chills, and diminished self) and well-being-related measures are mixed (Krenzer et al., 2020). According to research on the original version of the SAS, we investigated the associations between the SAS-J and psychological variables to confirm the convergent and criterion validity of the SAS-J.

Although situational awe is closely related to dispositional awe, it is conceptually distinguished. Situational awe reflects temporal awe experiences and is influenced differently by the type of awe, while dispositional awe is defined as individual differences in daily awe experiences and is independent of temporally emotional states. We also examined whether the SAS-J could be distinguished from a measure of dispositional awe (i.e., the Dispositional Awe Scale; Shiota et al., 2006) to confirm its discriminative validity.

It should also be noted that, although the SAS is useful for assessing two types of awe (Krogh-Jespersen et al., 2020; Price et al., 2021), it has one potential limitation. Although Krenzer et al. (2020) confirmed the factor structure of the SAS using an induction of positive awe, it remains unclear whether its factor structure would be independent of the valence of awe-experiences. Hence, we investigated whether the same factor structure would be validated in assessing threat-awe experiences.

In summary, we sought to examine the validity of the SAS-J similar to the original study (Krenzer et al., 2020) through three online surveys. In Study 1, we assessed situational positive-awe, two other awe-related variables (small self and dispositional awe), and five well-being-related variables (search for meaning in life, presence of meaning in life, daily gratitude, subjective happiness, and life satisfaction), using video clips, one of the most used methods to induce feelings of awe (Piff et al., 2015). We first confirmed whether the factor structure of the SAS-J would have the same structure (i.e., four-factor model) as the original SAS using a confirmatory factor analysis (CFA). Second, we investigated the correlation between the SAS-J subscales. Based on a previous study (Krenzer et al., 2020), we predicted that a correlation between connection and oppression would not be significant and that other correlations would be positively significant. To confirm the convergent and criterion validity, we investigated the correlations between the four SAS-J subscales and the Small-Self Scale (Piff et al., 2015), Dispositional Awe Scale (Shiota et al., 2006), Meaning in Life Questionnaire (Steger et al., 2006), Gratitude Questionnaire (McCullough et al., 2002), Subjective Happiness Scale (Lyubomirsky \& Lepper, 1999), and Satisfaction with Life Scale (Diener et al., 1985) based on the previous research (Krenzer et al., 2020). We predicted that connection, chills, 
and diminished self would be positively associated with small self and dispositional awe and that connection would also be positively associated with five well-being-related variables (i.e., search for meaning, presence of meaning, subjective happiness, daily gratitude, and life satisfaction). Based on the previous study (Krenzer et al., 2020), we did not hypothesize about the relationships between other SAS-J subscales and well-being-related variables.

In Study 2, we assessed situational threat-awe, small self, and dispositional awe to confirm the factor structure of the SAS-J and examine the correlations between the four subscales, utilizing the same method as used in Study $1 .{ }^{1} \mathrm{We}$ first predicted that the CFA would validate the four-factor model. We also predicted that a correlation between connection and oppression would not be significant, and that other correlations would be positively significant. Finally, we predicted that connection, chills, and diminished self would be positively associated with small self and dispositional awe. In addition, we investigated whether the SAS-J could differentiate between positive- and threat-awe using a combined dataset from studies 1 and 2. A previous study demonstrated that positive-awe increased subjective well-being compared with threat-awe (Gordon et al., 2017). Given that feelings of connection underlie the psychological mechanism for the relationship between awe and well-being (Krause \& Hayward, 2015), positive awe experiences should be more likely to induce higher levels of feelings of connection than threat-awe experiences. In contrast, as threat-awe induces lower levels of self-control and certainty and higher levels of powerlessness than positive-awe (Gordon et al., 2017), threat-awe should be more likely to induce higher levels of tense and oppressive feelings. We predicted that positiveawe would enhance connection compared to threat-awe, and that threat-awe would enhance oppression compared to positive awe.

In Study 3, we assessed the situational awe and dispositional awe after experiences of neutral emotion, positive awe, and threat-awe, to investigate whether the SAS-J could be distinguished from the Dispositional Awe Scale and could distinguish the two types of awe. We predicted that dispositional awe would not be influenced by the inductions of awe due to trait-level individual differences, while situational awe would be influenced by inductions of awe. We also predicted that positive awe would increase connection compared to neutral and threat-awe, and that threat-awe would increase oppression compared to neutral and positive-awe. The present study was approved by the Ethical

\footnotetext{
${ }^{1}$ As previous research has suggested that threat-awe did not increase well-being unlike positive-awe (Gordon et al., 2017), we did not investigate the relationships between the SAS-J subscales and five well-being-related scales in Study 2, in which we used an induction of threat-awe.
}

Review Board of the Graduate School of Education, Kyoto University (CPE-309).

\section{Study 1: Assessing a positive-awe experience}

In Study 1, we developed the SAS-J and examined whether it could measure positive awe experiences with validity.

\section{Methods}

\section{Participants}

A total of 619 Japanese participants were recruited via Crowd Works, a crowdsourcing service in Japan. Of these, 294 participants were excluded from the final analyses: 62 had too short (i.e., $<8$-min) or long (i.e., $>40$-min) response time for the entire survey, 14 for duplicated IP-address, and 218 for failing to correctly complete the two attention checks. ${ }^{2}$ In the final sample, 325 participants (mean $=37.17$, $S D=11.34$, range $=18-75 ; 188$ females, 135 males, 2 other) were analyzed. All participants provided written informed consent.

\section{Procedure}

This survey was conducted using Qualtrics (http://www. qualtrics.com). Participants were asked to provide informed consent before starting the survey. First, they watched a 2-min positive-awe-inducing video that consisted of a montage of beautiful nature clips, composed of glaciers, forests, mountains, and stars (Piff et al., 2015). This video was validated in a prior study (Takano \& Nomura, 2020). After watching the positive-awe-inducing clips, they completed measures of awe-experience, self-size, dispositional awe, well-being (meaning of life, subjective happiness, dairy gratitude, and life satisfaction), and demographic information (age and gender). The four well-being-related scales were presented in a random order.

\footnotetext{
${ }^{2}$ Many participants (32.63\%) were excluded from the two attention checks: 1) "Which was depicted in the video you watched? (1-Nature, 2-Human, 3-Archtecture, 4-Art, and 5-Other) Please be sure to select 'Other' to this question."; and 2) "At what time of the day are you currently participating this survey? (1-Morning, 2-Noon, 3-Evening, and 4-Night) Please be sure to select 'Evening' to this question.' Although the exclusion rate seems to be much higher, which might make it difficult to interpret the results, the main results (i.e., factor structure, internal reliability, inter-subscales correlation, convergent validity, and criterion validity) in both the samples excluding participants who failed in attention checks and including them were almost the same (see the supplementary information).
} 


\section{Materials}

\section{Awe experience}

We used the Japanese version of the sentence-formatted Situational Awe Scale to confirm the validity and reliability of this scale. First, the first author obtained permission to translate the SAS from the original authors and translated the SAS from English into Japanese, the second author checked it, and we discussed and modified it. Next, we backtranslated all the translated items and confirmed the semantic equivalence to the original SAS via ulatus (https://www. ulatus.jp). The SAS consisted of 15 items. Participants were asked to respond with their agreement from 1 (not at all) to 7 (very much) for each statement (Cronbach's $\alpha$ s $\geq 0.61$ ).

\section{Small self}

We measured the participants' smaller self-size after they watch the awe-inducing clips using the Japanese version (Nomura, 2021) of the Small-Self Scale (Piff et al., 2015). It consisted of 10 items (e.g., "I feel the presence of something greater than myself," and "I feel small or significant"). Participants were asked to respond with their agreement from 1 (strongly disagree) to 7 (strongly agree) for each statement $(\alpha=0.88)$.

\section{Dispositional awe}

We measured the participants' dispositional awe using the Japanese version (Nomura et al. 2022) of the Dispositional Awe Scale (Shiota et al., 2006). It consisted of six items (e.g., "I often feel awe," and "I feel wonder almost every day.") Participants were asked to respond with their agreement from 1 (strongly disagree) to 7 (strongly agree) for each statement $(\alpha=0.75)$.

\section{Meaning in life}

We measured the participants' meaning in life using the Japanese version (Shimai et al., 2019) of the Meaning in Life Questionnaire (Steger et al., 2006). It consisted of two subscales: search for meaning in life (five items, e.g., "I am looking for something that makes my life feel meaningful.") and presence of meaning in life (five items, e.g., "I understand my life's meaning."). Participants were asked to respond with agreement from 1 (absolutely untrue) to 7 (absolutely true) for each statement (search for meaning: $\alpha=0.89$; presence of meaning: $\alpha=0.87$ ).

\section{Subjective happiness}

We measured the participants' subjective happiness by using the Japanese version of (Shimai et al., 2004) the Subjective Happiness Scale (Lyubomirsky \& Lepper, 1999). It consisted of the four following items that were rated on a 7-point Likert scales: "In general, I consider myself..." (1 (a not very happy person) to 7 (a very happy person)), "Compared to most of my peers, I consider myself...," (1 (less happy) to 7 (more happy)), "Some people are generally very happy. They enjoy life regardless of what is going on, getting the most out of everything. To what extent does this characterization describe you?." (1 (not at all) to 7 (a great deal)), and "Some people are generally not very happy. Although they are not depressed, they never seem as happy, as they might be. To what extent does this characterization describe you?" (reversed item) $(1$ (not at all) to 7 (a great deal)) $(\alpha=0.87)$.

\section{Gratitude}

We measured the participants' dairy gratitude by using the Japanese version (Shiraki \& Igarashi, 2014) of the Gratitude Questionnaire (McCullough et al., 2002). It consisted of six items (e.g., "I have so much in life to be thankful for," and "If I had to list everything that I felt grateful for, it would be a very long list.") Participants were asked to respond with agreement from 1 (strongly disagree) to 7 (strongly agree) for each statement $(\alpha=0.82)$.

\section{Life satisfaction}

We measured the participants' life satisfaction by using the Japanese version (the upper part of the scales available on the Diener's homepage (http://labs.psychology.illinois.edu/ ediener/SWLS.html)) of the Satisfaction with Life Scale (Diener et al., 1985). It consisted of five items (e.g., "In most way my life is close to ideal," and "I am satisfied with life."). Participants were asked to respond with agreement from 1 (strongly disagree) to 7 (strongly agree) for each statement $(\alpha=0.84)$.

\section{Results and Discussion}

\section{Structural validity}

We conducted a CFA to examine the factor structure of the SAS-J by using the lavaan package (Rosseel, 2012) in R (R Core Team, 2021) (see Table 1). As predicted, the CFA showed that the four-factor model provided an adequate fit to the data (Comparative Fit Index $(\mathrm{CFI})=0.90$, Tucker-Lewis Index $(\mathrm{TLI})=0.87$, Root Mean Square Error of Approximation $($ RMSEA $)=0.087$, and Standardized Root Square 
Table 1 Items in the Japanese version of the Situational Awe Scale and results of the confirmatory factor analysis in study 1 and 2

\begin{tabular}{|c|c|c|c|c|c|c|c|c|c|}
\hline \multirow{2}{*}{$\overline{\text { Items }}$} & & \multicolumn{4}{|c|}{ Study $1(N=325)$} & \multicolumn{4}{|c|}{ Study $2(N=291)$} \\
\hline & & F1 & F2 & F3 & $\mathrm{F} 4$ & $\mathrm{~F} 1$ & $\mathrm{~F} 2$ & F3 & $\mathrm{F} 4$ \\
\hline 1 & $\begin{array}{l}\text { 本来の自分のあり方とむすびついているように感じる } \\
\text { I felt a closer sense of my identity, who I am }\end{array}$ & .65 & & & & .60 & & & \\
\hline 2 & $\begin{array}{l}\text { 周囲のあらゆる人/モノ心理的につながっていると感゙゙る } \\
\text { I felt psychologically connected to everyone/everything around me }\end{array}$ & .86 & & & & .84 & & & \\
\hline 3 & $\begin{array}{l}\text { 周囲のあらゆる人/モノ身体的につながっていると感じる } \\
\text { I felt physically connected to everyone/everything around me }\end{array}$ & .82 & & & & .83 & & & \\
\hline 4 & $\begin{array}{l}\text { すジてがお互いにつながっているように思える } \\
\text { Everything seemed connected }\end{array}$ & .81 & & & & .77 & & & \\
\hline 5 & $\begin{array}{l}\text { 窮屈さむ感じる } \\
\text { I felt confined }\end{array}$ & & .54 & & & & .39 & & \\
\hline 6 & $\begin{array}{l}\text { 緊迫感を感゙゙る } \\
\text { I felt suffocated }\end{array}$ & & .69 & & & & .75 & & \\
\hline 7 & $\begin{array}{l}\text { 息苦しさを感゙る } \\
\text { I felt oppressed }\end{array}$ & & .83 & & & & .78 & & \\
\hline 8 & $\begin{array}{l}\text { 息の詰まるような感覚を覚える } \\
\text { I felt tense }\end{array}$ & & .80 & & & & .83 & & \\
\hline 9 & $\begin{array}{l}\text { 心臓がドキドキしている } \\
\text { My heart was racing }\end{array}$ & & & .72 & & & & .80 & \\
\hline 10 & $\begin{array}{l}\text { はっと息をのんだ } \\
\text { My breath was taken away }\end{array}$ & & & .62 & & & & .70 & \\
\hline 11 & $\begin{array}{l}\text { ゾクゾクする } \\
\text { I felt chills }\end{array}$ & & & .72 & & & & .71 & \\
\hline 12 & $\begin{array}{l}\text { 鳥肌が立つ } \\
\text { I felt goosebumps }\end{array}$ & & & .77 & & & & .75 & \\
\hline 13 & $\begin{array}{l}\text { 自分の身体をよりちっぽけに感じる } \\
\text { I felt physically smaller }\end{array}$ & & & & .71 & & & & .79 \\
\hline 14 & $\begin{array}{l}\text { 壮大な物事の枠組みのなかで、自分が取るに足らないように感じる } \\
\text { I felt like I was trivial, in the grand scheme of things }\end{array}$ & & & & .67 & & & & .78 \\
\hline \multirow[t]{6}{*}{15} & $\begin{array}{l}\text { 世界が広大であるように思える } \\
\text { The world seemed vast }\end{array}$ & & & & .41 & & & & .56 \\
\hline & Inter-factor correlations & $\mathrm{F} 1$ & $\mathrm{~F} 2$ & $\mathrm{~F} 3$ & $\mathrm{~F} 4$ & $\mathrm{~F} 1$ & $\mathrm{~F} 2$ & F3 & $\mathrm{F} 4$ \\
\hline & $\mathrm{F} 1$ & - & .01 & .42 & .47 & - & .05 & .18 & .39 \\
\hline & $\mathrm{F} 2$ & .01 & - & .58 & .20 & .05 & - & .81 & .30 \\
\hline & F3 & .42 & .58 & - & .52 & .18 & .81 & - & .47 \\
\hline & F4 & .47 & .20 & .52 & - & .39 & .30 & .47 & - \\
\hline
\end{tabular}

F1: connection [つながり], F2: oppression [圧迫感], F3: chills [鳥肌感], and F4: diminished self [ちっぽけな自己]. Instruction sentences: How much do you agree with each of the following statements now? Please indicate your agreement with each item by checking the appropriate scale form “not at all” to “strongly agree.” [以下のそれぞれの項目について, 今のあなたにはぼれくらいあてはまりますか.「全くあてはまらない」から「非 常にあてはまる」までのなかから,あてはまるところに○をしてください.]

Residual $($ SRMR $)=0.084)$. Although we also investigated the validity of the higher-order models as Krenzer et al. (2020)'s Study 2 has selected a high-order model, the results indicated that the higher-order models did not converge. To search for a more valid factorial structure of the SAS-J, we also conducted an Exploratory Factor Analysis (EFA). ${ }^{3}$

\footnotetext{
${ }^{3}$ Following the reviewer's comment, we conducted the Exploratory Factor Analysis. We thank the reviewer for the insightful comments to the manuscript
}

The scree plot demonstrated that a four-factor solution was appropriate for the data (Figure S1). The EFA using the maximum likelihood estimation and Promax rotation also demonstrated that the SAS-J consisted of the same four factors as the previous study (Krenzer et al., 2020).

\section{Reliability}

All composite and subscale scores were calculated by averaging the scores across the relevant items, given an inverse score, if necessary. Descriptive statistics (mean, $S D$, and 
Table 2 Descriptive statistics (Mean, SD, and Cronbach's coefficient alpha) in study 1 and 2

\begin{tabular}{|c|c|c|c|c|c|c|}
\hline \multirow[b]{2}{*}{ Variables } & \multicolumn{3}{|c|}{ Study 1 (Positive Awe) } & \multicolumn{3}{|c|}{ Study 2 (Threat-Awe) } \\
\hline & Mean & $S D$ & $\alpha$ & Mean & $S D$ & $\alpha$ \\
\hline SAS-J total & 3.80 & 0.89 & .83 & 3.97 & 0.97 & .84 \\
\hline SAS-J connection & 3.69 & 1.35 & .86 & 3.17 & 1.33 & .84 \\
\hline SAS-J oppression & 3.13 & 1.33 & .80 & 4.02 & 1.41 & .78 \\
\hline SAS-J chills & 3.67 & 1.32 & .80 & 4.05 & 1.47 & .83 \\
\hline SAS-J diminished self & 5.03 & 1.17 & .61 & 4.85 & 1.43 & .74 \\
\hline Small Self & 4.38 & 1.13 & .88 & 4.32 & 1.23 & .89 \\
\hline Dispositional Awe & 3.77 & 0.98 & .75 & 3.76 & 1.08 & .76 \\
\hline Search for Meaning & 4.77 & 1.19 & .89 & - & - & 一 \\
\hline Presence in Meaning & 3.69 & 1.30 & .87 & - & - & - \\
\hline Life Satisfaction & 4.27 & 1.13 & .87 & - & - & - \\
\hline Gratitude & 5.04 & 0.97 & .82 & - & - & 一 \\
\hline Subjective Happiness & 3.58 & 1.20 & .84 & - & - & - \\
\hline
\end{tabular}

SAS-J = Japanese version of the Situation Awe Scale. For all scales and subscales, possible range $=1$ to 7
Cronbach's coefficient alpha) and the inter-scale correlations for the SAS-J and all other measures are presented in Tables 2 and 3. The composite and four subscale measures all demonstrated moderate reliability (SAS-J total: $\alpha=0.83$; connection: $\alpha=0.86$; oppression: $\alpha=0.80$; chills: $\alpha=0.80$; diminished self: $\alpha=0.61$ ), almost consistent with the original report (Krenzer et al., 2020, study2: total: $\alpha=0.84$; connection: $\alpha=0.83$; oppression: $\alpha=0.82$; chills: $\alpha=0.78$; diminished self: $\alpha=0.65$ ).

The inter-scale correlations for the four SAS-J subscales also provided the validity. As predicted, the correlation between connection and oppression was insignificant $(r(323)=0.02,95 \%$ CI $[-0.09,0.13], p=0.77)$, and all other correlations between the four subscales were positively significant ( $r \mathrm{~s} \geq 0.12, p s \leq 0.03$, see Table 3 ), which was consistent with the original version of the SAS (Krenzer et al., 2020).

\section{Convergent validity}

We examined whether the four SAS-J sub-components correlated with the small self and dispositional awe to confirm convergent validity. As predicted, scores on the connection, chills, and diminished self subscales were positively correlated with both scores on the Small Self Scale and Dispositional Awe Scale ( $r s \geq 0.20, p s<0.001)$.

Criterion validity.

We examined whether the four SAS-J sub-components correlated with the search for meaning, presence of meaning, subjective happiness, gratitude, and life satisfaction. Contrary to our prediction, scores on the connection subscale correlated positively with scores on four well-being-related measures excluding the Subjective Happiness Scale (Subjective Happiness Scale: $r(323)=0.10, p=0.08,95 \%$ CI [-0.01, 0.20]; others: $r \mathrm{~s} \geq 0.17, p s \leq 0.002$ ). The results were mixed for oppression, chills, and diminished self subscales. These results were almost consistent with that of a previous research (Krenzer et al., 2020), which suggested that the SAS-J has the criterion validity. Interestingly, our results demonstrated that scores on the connection subscale were not positively correlated with scores on the Subjective Happiness Scale, which were inconsistent with the previous Western research (Krenzer et al., 2020). It should be noted that, although Japanese people are considered to emphasize interdependent happiness and social harmony in subjective well-being when compared to North Americans (Hitokoto \& Uchida, 2015; Uchida \& Kitayama, 2009), the Subjective Happiness Scale includes more items that measure and compare the extent of individual's happiness than other scales that measure well-being (Lyubomirsky \& Lepper, 1999; Shimai et al., 2004). Therefore, in terms of the interdependent happiness, the present study results suggest that feelings of connection with others may not be associated with feelings of being happier among Japanese people in comparison with other cultures.

In summary, we examined whether the SAS-J could be validated from the perspectives of structural validity, reliability, convergent validity, and criterion validity by using the induction of positive awe. The results supported the fourfactor structure and provided the evidence for reliability, convergent validity, and criterion validity. However, it remained unclear whether the SAS-J could assess a threat-awe experience with validity. Hence, in Study 2, we examined whether the SAS-J would be validated when assessing threat-awe experiences. 


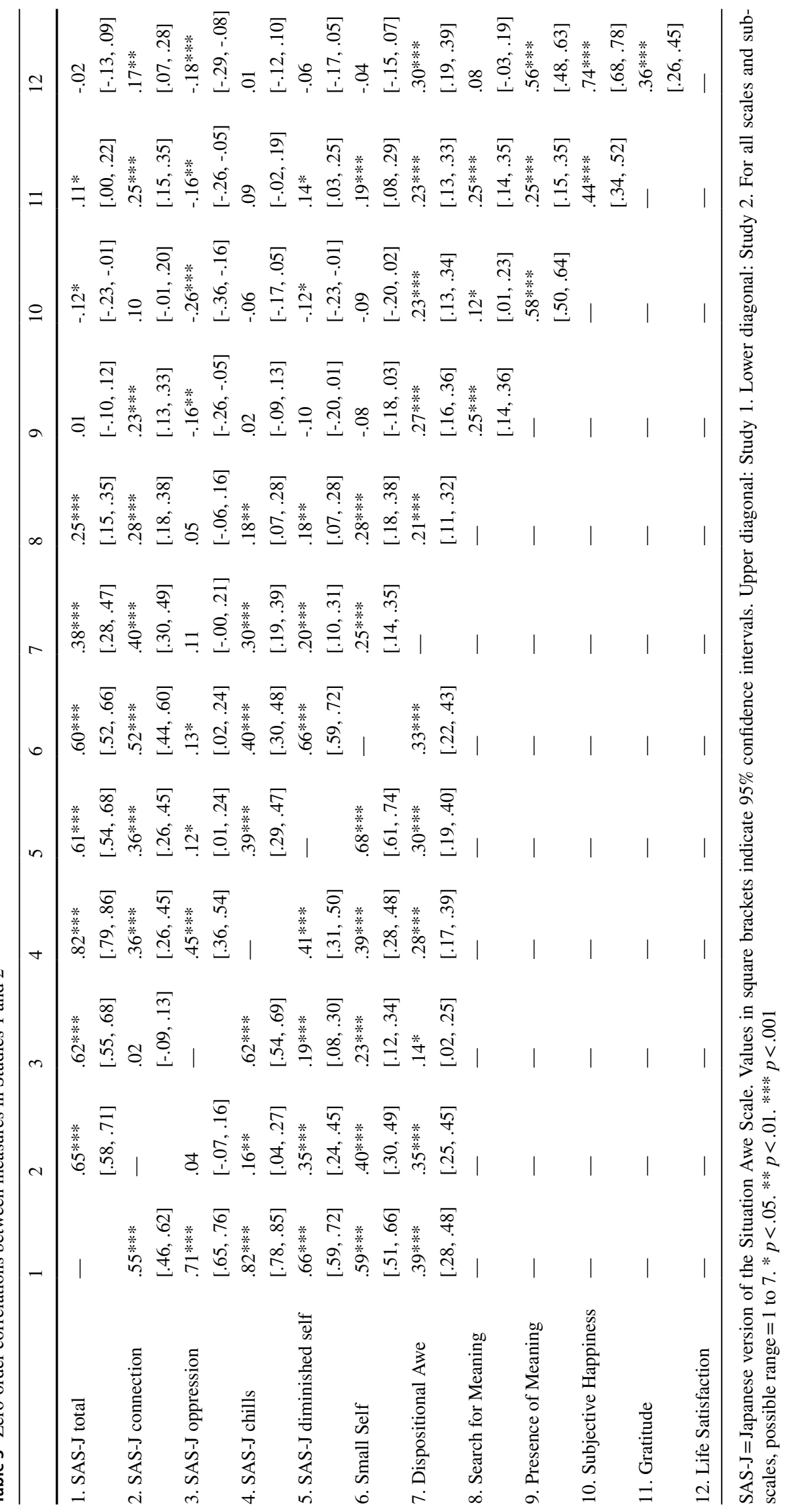


Table 4 Situational Awe and Dispositional Awe Across Conditions (Study 3)

\begin{tabular}{|c|c|c|c|c|c|c|}
\hline \multirow[b]{2}{*}{ Variables } & \multicolumn{2}{|l|}{$\begin{array}{l}\text { Neutral } \\
(\mathrm{N}=140)\end{array}$} & \multicolumn{2}{|l|}{$\begin{array}{l}\text { Positive Awe } \\
(\mathrm{N}=136)\end{array}$} & \multicolumn{2}{|l|}{$\begin{array}{l}\text { Threat-Awe } \\
(\mathrm{N}=142)\end{array}$} \\
\hline & Mean $(S D)$ & & Mean $(S D)$ & & Mean (SD) & \\
\hline SAS-J total & $2.68(0.80)$ & $b, c$ & $3.63(0.99)$ & $\mathrm{a}$ & $3.75(0.92)$ & a \\
\hline SAS-J connection & $3.05(1.15)$ & b & $3.61(1.40)$ & a, b & $3.22(1.11)$ & b \\
\hline SAS-J oppression & $2.55(1.28)$ & c & $2.89(1.25)$ & c & $3.62(1.29)$ & $\mathrm{a}, \mathrm{b}$ \\
\hline SAS-J chills & $1.85(0.82)$ & $b, c$ & $3.38(1.29)$ & $\mathrm{a}$ & $3.52(1.41)$ & $\mathrm{a}$ \\
\hline SAS-J diminished self & $3.49(1.22)$ & $b, c$ & $4.97(1.36)$ & a & $4.94(1.15)$ & a \\
\hline Dispositional Awe & $3.46(0.99)$ & & $3.40(1.06)$ & & $3.48(0.99)$ & \\
\hline
\end{tabular}

SAS-J = Japanese version of Situation Awe Scale. ${ }^{a}$ Mean is different from neutral. ${ }^{b}$ Mean is different from positive awe. ${ }^{\mathrm{c}}$ Mean is different from threat-awe at Bonferroni adjusted $p<.05$. For all scales and subscales, possible range $=1$ to 7

\section{Study 2: Assessing a threat-awe experience}

In Study 2, we investigated whether the SAS-J could measure threat-awe experiences with validity. We also examined whether the SAS-J could discriminate between positive- and threat-awe by comparing the results of studies 1 and 2 .

\section{Method}

\section{Participants}

We recruited 594 Japanese participants were recruited via Crowd Works. Of these, 331 participants were excluded from the final analyses: 71 had for too short (i.e., $<8$-min) or long (i.e., $>40-\mathrm{min}$ ) response time for the entire survey, 20 for duplicated IP-address, and 212 for failing to correctly complete the two attention checks. ${ }^{4}$ In the final sample, 291 participants ( mean age $=35.49, S D=10.50$, range $=20-66$; 167 females, 123 males, 1 other) were analyzed. All participants provided written informed consent.

\section{Procedure}

This survey was also conducted in Qualtrics. Participants were asked to provide informed consent before starting the survey. First, they watched a 2-min threat-awe-inducing video that consisted of a montage of threat-based nature clips, composed of tornados, thunder, volcano, and avalanche (Gordon et al., 2017). This video was validated in

\footnotetext{
${ }^{4}$ Many participants (35.69\%) were excluded for the same two attention checks as Study 1. Although the exclusion rate was much higher, which might make it difficult to interpret the results, the main results (i.e., factor structure, internal reliability, inter-subscales correlation, and convergent validity) in both the samples excluding participants who failed in attention checks and sample including them were almost the same (see the supplementary information).
}

a previous study (Takano \& Nomura, 2020). After watching the threat-awe-inducing clips, they completed measures of awe-experience, self-size, dispositional awe, and demographic information (age and gender).

\section{Materials}

We used the same scales as used in Study 1.

\section{Results and Discussion}

\section{Structural validity}

We conducted a CFA to examine the factor structure of the SAS-J (see Table 1). As predicted, the CFA showed that the four-factor model provided an adequate fit to the data $(\mathrm{CFI}=0.91$, TLI $=0.89, \mathrm{RMSEA}=0.082$, and SRMR $=0.067)$. These were similar to the results of Study 1 .

All composite and subscale scores were calculated by averaging the scores across the relevant items, given an inverse score, if necessary. Descriptive statistics (mean, $S D$, and Cronbach's coefficient alpha) and the inter-scale correlations for the SAS-J and all other measures are presented in Tables 2 and 4 . The composite and four subscale measures all had good reliability (SAS-J total: $\alpha=0.84$; connection: $\alpha=0.84$; oppression: $\alpha=0.78$; chills: $\alpha=0.83$; diminished self: $\alpha=0.74$ ), which were similar to the results of the original report (Krenzer et al., 2020) and Study 1.

The inter-scale correlations for the four SAS-J subscales also provided the validity. As predicted, the correlation between connection and oppression was insignificant $(r(289)=0.04,95 \% \mathrm{CI}[-0.07,0.16], p=0.45)$, and all other correlations between the four subscales were positively significant ( $r \mathrm{~s} \geq 0.16, p \mathrm{~s} \leq 0.007$, see Table 4), which was consistent with the previous research (Krenzer et al., 2020) and Study 1. 
Fig. 1 Connection and oppression in study 1 (positive-awe) and 2 (threat-awe). Note. Error bars represent $95 \%$ confidence intervals
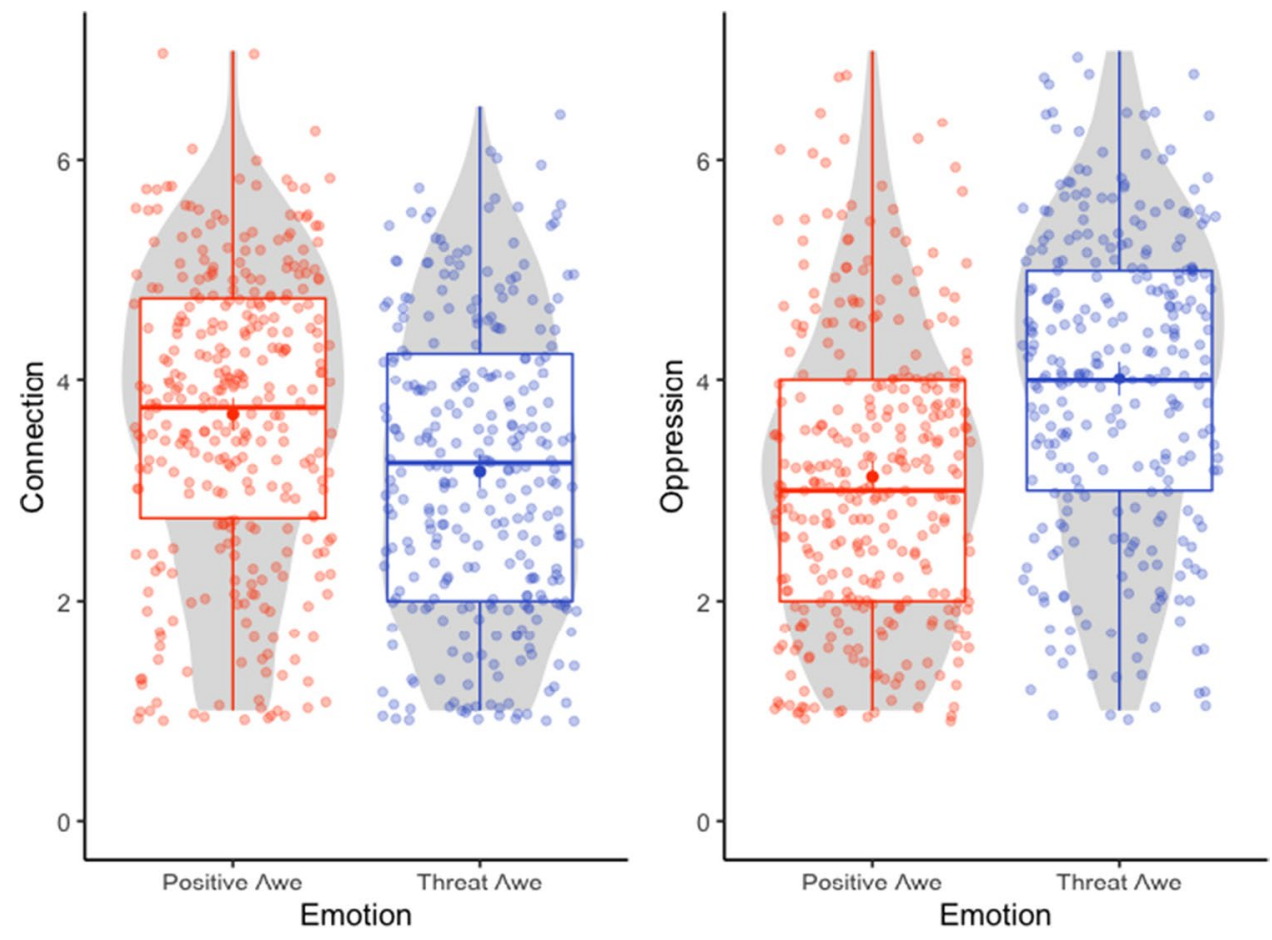

\section{Convergent validity}

We examined whether the four SAS-J sub-components correlated with the small self and dispositional awe to confirm convergent validity. As predicted, scores on the connection, chills, and diminished self subscales were positively correlated with both scores on the small self and dispositional awe measures $(r s \geq 0.28, p s<0.001)$. Interestingly, scores on the oppression subscale were also positively correlated with scores on the Dispositional Awe Scale $(r(289)=0.14$, 95\% CI [0.02, 0.25], $p=0.02$ ).

Differences between positive- and threat-awe.

To confirm whether the SAS-J would be able to differentiate between the two types of awe, we conducted independent $t$-tests on the scores of the connection and oppression subscales using a combined dataset (i.e., study 1: positiveawe condition; study 2: threat-awe condition; see Fig. 1). As expected, the independent $t$-tests showed that while participants in the positive awe condition reported higher scores on connection than participants in the threat-awe condition $(t(608.17)=4.80, p<0.001, d=0.39,95 \%$ CI $[0.22,0.55])$, the latter reported higher scores on oppression than the former $(t(596.99)=8.08, p<0.001, d=0.65,95 \%$ CI $[0.49$, $0.82]$ ). Consistent with previous research (Krenzer et al., 2020), these results indicated that the SAS-J could differentiate between positive- and threat-awe experiences.
In summary, we examined whether the SAS-J was validated from the perspectives of structural validity, reliability, and convergent validity using the induction of threat-awe. The results supported the four-factor structure and provided the evidence for reliability and convergent validity, which suggested that the SAS-J could measure experiences of threat-awe. In contrast, it remains unclear whether the state-scale SAS-J was distinguished from the existing awe-related measure (i.e., Dispositional Awe Scale; Shiota et al., 2006), which was a trait-scale. We also demonstrated that positive awe enhanced feelings of connectedness compared to threat-awe, and threatawe induced feelings of oppression compared to positive awe. Given the lack of non-awe control conditions (e.g., neutral condition) in Studies 1 and 2, the next step of this research was to examine whether positive- and threat-awe experiences enhance feelings of connection and oppression more than neutral emotions, respectively. Therefore, in Study 3, we investigated the discriminative validity of situational awe and dispositional awe measurements and compared the effects of neutral, positiveawe, and threat-awe on connection, oppression, chills, and diminished self. Additionally, although we used awe-inducing video clips validated in previous research (Piff et al., 2015; Takano \& Nomura, 2020) in Studies 1 and 2, it remains unclear whether participants felt awe in the two studies as the two studies did not include a self-reported manipulation check. Hence, we also added a self-reported manipulation check in Study 3. 


\section{Study 3: Assessing positive- and threat-awe}

In Study 3, we investigated the discriminative validity between the SAS-J and the Dispositional Awe Scale. We also added a neutral condition and compared two types of awe experiences with a neutral emotional state.

\section{Method}

\section{Participants}

We recruited 476 Japanese participants were recruited via Crowd Works. Power analysis using the 'pwr.t.test' function from the $p w r$ package (Champely, 2020) indicated that the required sample size was $141 \times 3$ (i.e., 423) to detect an effect size calculated in Study 2 (i.e., $d=0.39$ ) in a twosample t-test, with $\alpha=0.016$ and $\beta=0.80$. Of these, 58 participants were excluded from final analyses: 10 had for too short (i.e., $<4-\mathrm{min}$ ) or long (i.e., $>20$-min) response time for the entire survey, 39 for duplicated IP-address, and nine for failing to correctly complete the attention check. ${ }^{5}$ In final sample, 418 participants (mean age $=42.30, S D=9.96$, range $=20-73 ; 201$ females, 217 males) were analyzed. All participants provided written informed consent.

\section{Procedure}

This survey was conducted using Qualtrics. Participants were asked to provide informed consent before starting the survey. First, they watched one of three 2-min emotioninducing videos: a neutral clip that comprised of an automobile company advertisement (Takano \& Nomura, 2020), positive-awe-inducing clips that consisted of a montage of beautiful nature clips composed of glaciers, forests, mountains, and stars (Piff et al., 2015), and threat-awe-inducing clips that consisted of a montage of threat-based nature clips, composed of tornados, thunder, volcano, and avalanche (Gordon et al., 2017). These videos were validated in a previous study (Takano \& Nomura, 2020). After watching one of three video clips, they completed the measures of emotional state, awe-experience, dispositional awe, and demographic information (age and gender).

\footnotetext{
5 As many participants were excluded for the attention check in Studies 1 and 2, we used an attention check question different from two studies in Study 3. As the attention check, the item "*Please be sure to select 'almost disagree' to this item." was included in the Emotion scale.
}

\section{Materials}

\section{Emotion}

We used these emotion reports to confirm that the participants felt awe while watching the two awe-inducing videos. All participants reported the extent to which they felt: "ikei," "ifu" (awe in Japanese; Muto, 2014), wonder, fear, anxiety, amusement, happy, gratitude, respect, joy, sad, anger, cold, warmth, nervous, and satisfaction, rated on a 9-point Likert scale from 1 (not at all) to 9 (extremely). This measure was based on previous research (Gordon et al., 2017). Additionally, the attention check item was included in this measure. According to previous research (Takano \& Nomura, 2021), we used the mean scores of $i k e i, i f u$, and wonder as awe scores.

Awe experience and dispositional awe.

We used the same scales as used in studies 1 and 2 .

\section{Results and Discussion}

\section{Self-reported manipulation check}

We conducted an analysis of variance (ANOVA) on the awe score to confirm that the positive- and threat-awe-inducing videos induced feelings of awe compared to the neutral video. The results showed that awe scores were significantly higher in the positive-awe condition (positive-awe: $M=5.53, S D=1.90 ; t(248.84)=12.14, p<0.001, d=1.47$, $95 \%$ CI $[1.18,1.82])$ and threat-awe condition $(M=6.06$, $S D=1.47 ; t(279.81)=17.38, p<0.001, d=2.07,95 \% \mathrm{CI}$ $[1.75,2.46])$ compared to the neutral condition $(M=3.09$, $S D=1.41)$. These results suggested that the induction of emotions was validated.

\section{Awe experience}

We conducted ANOVAs on the scores on the four SAS-J subscales (see Fig. 2 and Table 4). As predicted, the results showed that the scores on connection were significantly higher in the positive-awe condition $(M=3.61$, $S D=1.40)$ compared to the neutral $(M=3.05, S D=1.15$; $t(260.69)=3.63, p<0.001, d=0.44,95 \%$ CI $[0.19$, $0.68])$ and threat-awe conditions $(M=3.22, S D=1.11$; $t(256.60)=2.54, p=0.035, d=0.31,95 \%$ CI $[0.06,0.54])$, but there was no significant difference between the threatawe condition and the neutral condition $(t(279.26)=0.19$, $p=0.58, d=0.16,95 \%$ CI $[-0.08,0.39])$. Additionally, the scores on oppression were significantly higher in the threat-awe condition $(M=3.62, S D=1.29)$ compared to the neutral $(M=2.55, S D=1.28 ; t(279.99)=7.01$, 
Fig. 2 Connection and oppression in study 3. Note. Error bars represent $95 \%$ confidence intervals
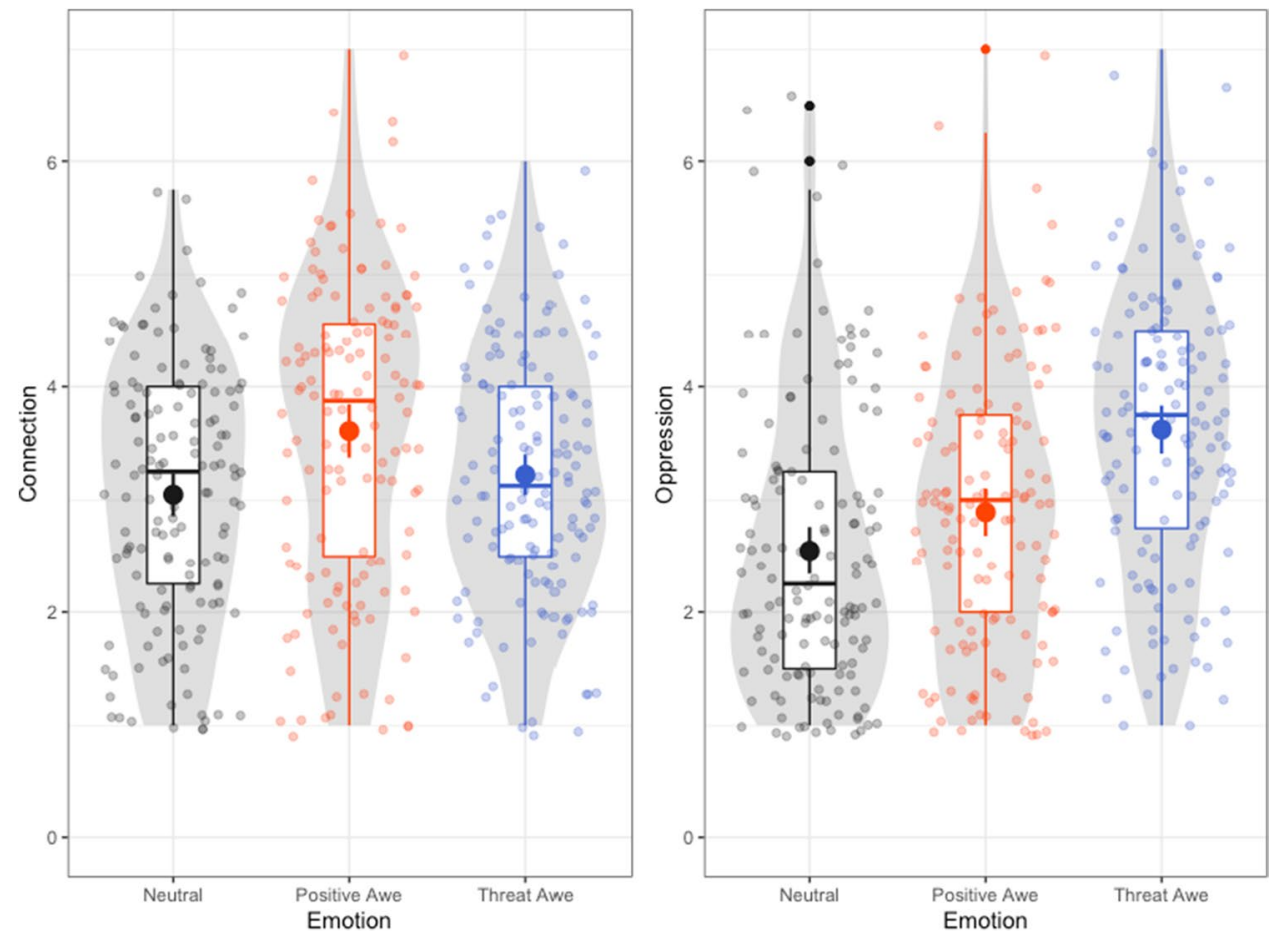

$p<0.001, d=0.83,95 \% \mathrm{CI}[0.58,1.12])$ and positiveawe conditions $(M=2.89, S D=1.25 ; t(275.96)=4.79$, $p<0.001, d=0.58,95 \%$ CI $[0.34,0.84])$, but there was no significant difference between the positive-awe and neutral conditions $(t(273.99)=2.24, p=0.077, d=0.27,95 \%$ CI $[0.03,0.52])$. Moreover, results showed that the scores on chills and diminished self were significantly higher in the positive-awe condition (chills: $M=3.38, S D=1.29$; $t(228.67)=11.78, p<0.001, d=1.42,95 \%$ CI $[1.18,1.72]$; diminished self: $M=4.97, S D=1.36 ; t(268.80)=9.52$, $p<0.001, d=1.15,95 \%$ CI $[0.88,1.44])$ and threat-awe condition (chills: $M=3.52, S D=1.41 ; t(228.11)=12.23$, $p<0.001, d=1.45,95 \%$ CI [1.22, 1.72]; diminished self: $M=4.94, S D=1.15 ; t(268.80)=9.52, p<0.001$, $d=1.22,95 \%$ CI $[0.95,1.52])$ compared to the neutral condition (chills: $M=1.85, S D=0.82$; diminished self: $M=3.49, S D=1.22$ ), but there was no significant differences between the positive-awe and threat-awe conditions (chills: $t(275.42)=0.87, p=1.00, d=0.10,95 \%$ CI $[-0.35$, $0.14]$; diminished self: $t(264.78)=0.19, p=1.00, d=0.02$, $95 \%$ CI $[-0.21,0.26])$. These findings not only replicated the results of Study 2, but also suggested that the SAS-J differentiated between positive- and threat-awe from the perspective of comparison with a neutral state.

We also conducted correlation analyses between the emotion scores and SAS-J scores to confirm that the SAS-J captured feelings of awe (see Table 5). The results revealed that awe ratings were positively correlated with the scores on the SAS-total, connection, chills, and diminished self in the positive-awe condition $(r s \geq 0.35, p s \leq 0.001)$ and with the scores on the SAS-total, oppression, chills, and diminished self in the threat-awe condition $(r s \geq 0.25$, $p s \leq 0.002)$. These results suggested that the SAS-J captured both awe experiences. Interestingly, the scores on the SAS-J total and four subscales were slightly more correlated with the scores on some emotions than the scores on ikei, ifu, wonder, and awe. In particular, the scores on sadness were also positively correlated with the scores on the SAS-total, connection, chills, and diminished self in the positive-awe condition ( $\mathrm{rs} \geq 0.19$, $\mathrm{ps} \leq 0.03$ ) and with the scores on the SAS-total, oppression, chills, and diminished self in the threat-awe condition $(r s \geq 0.25$, $p s \leq 0.002$ ). Next, we conducted partial correlation analyses between awe, sad, and SAS-J scores to confirm that the SAS-J captured awe experiences rather than sad experiences. The results demonstrated that awe scores were also positively correlated with the scores on the SAS-total, connection, chills, and diminished self in the positive-awe condition ( $r s \geq 0.32$, ps $<0.001$ ) and with the scores on the SAS-total, oppression, chills, and diminished self in the threat-awe condition $(r s \geq 0.23, p s \leq 0.007)$, when controlled for sad scores. Conversely, the results of partial correlations between sad scores and the SAS-J total, connection, chills, and diminished self subscale scores in the positive awe condition when controlled for awe scores were mixed ( $r \mathrm{~s} \geq 0.10, p s \leq 0.27$ ), while the results of partial correlations between sad scores and the SAS-J total, oppression, chills, and diminished self subscale scores in the threat awe condition when controlled for awe scores were positively significant ( $r \mathrm{~s} \geq 0.22, p s \leq 0.009)$. Hence, 


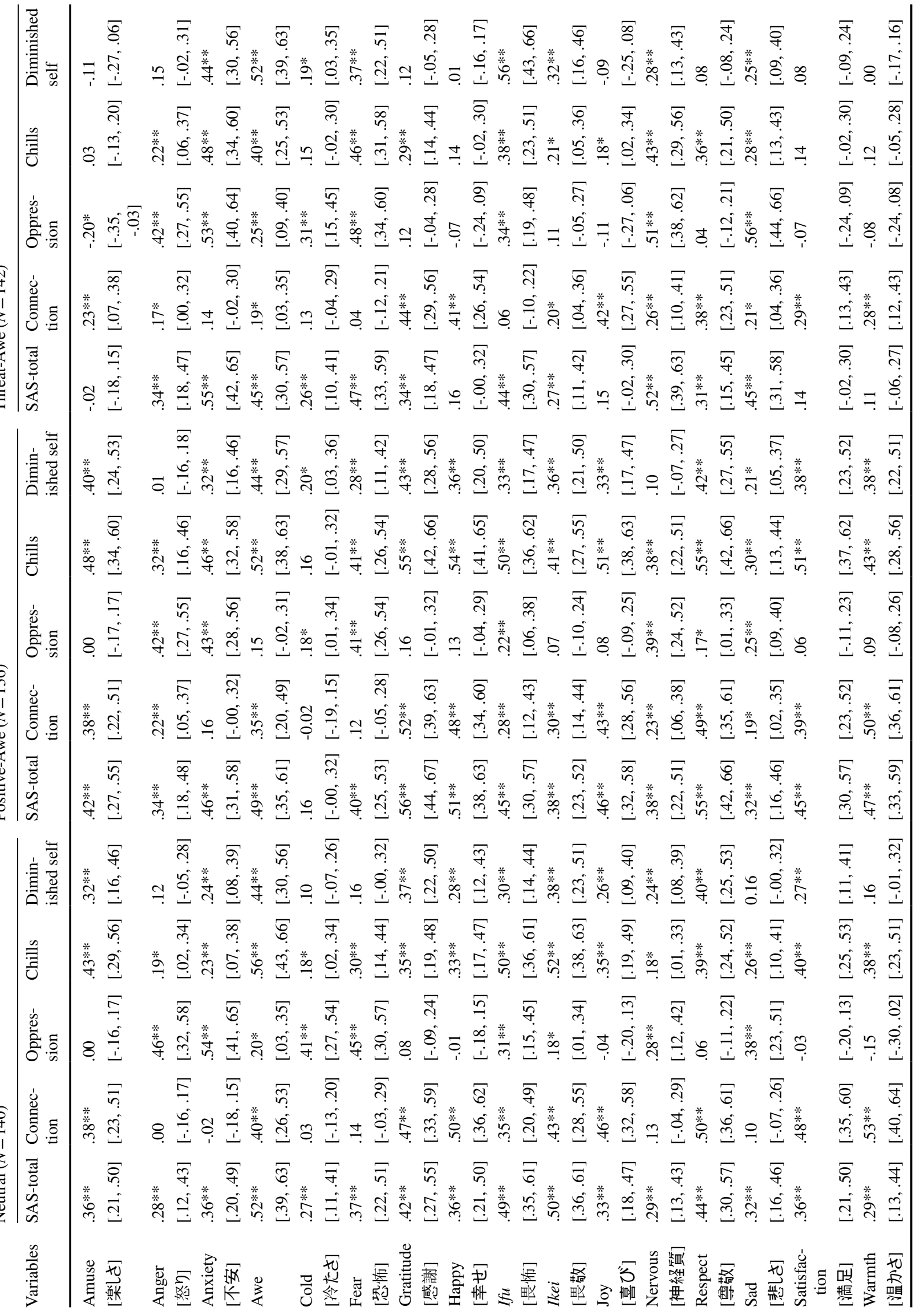


these results suggested that the SAS-J captured awe rather than other emotions.

\section{Discriminative validity}

We conducted an ANOVA on the dispositional awe scores to investigate the discrimination validity between the SAS-J and Dispositional Awe Scale. We utilized a multiple imputation method using the mi.anova function in the miceadds package (Robitzsch \& Grund, 2021) as there were some missing values in the dataset. As predicted, the results showed that scores on dispositional awe scale did not significantly differ among the three conditions (neutral: $M=3.46, S D=0.99$; positive-awe: $M=3.40, S D=1.06$; threat-awe: $M=3.48, S D=0.99 ; F(2,23,555.01)=0.23$, $p=0.79)$. Given that the scores on the four SAS-J subscales differed among the three conditions $(F \mathrm{~s} \geq 7.59$, $\left.p \mathrm{~s}<0.001, \eta_{p}{ }^{2} \mathrm{~s} \geq 0.035\right)$, these results suggested that the SAS-J was distinguished from the Dispositional Awe Scale.

\section{General Discussion}

This study aimed to develop and validate the SAS-J and to confirm whether it could differentiate between positiveand threat-awe, using awe-inducing video clips. The results of the CFA showed that the SAS-J consisted of four factors that assessed both positive-and threat-awe experiences. Our results also confirmed the reliability, convergent, criterion, and discriminative validity of the SAS-J. Moreover, the results demonstrated that the SAS-J could differentiate between positive- and threat-awe experiences. Hence, our results suggest that the SAS-J could measure threatawe experiences as well as positive-awe experiences with validity.

\section{Connection}

The results showed that positive awe increased the feeling of connectedness, which was consistent with much previous research (Bai et al., 2017; Krenzer et al., 2020; NelsonCoffey et al., 2019; Shiota et al., 2007; Stellar et al., 2017; van Cappellen \& Saroglou, 2012; Yaden et al., 2019). Previous research has also suggested that positive awe experience enhanced well-being through various psychological mechanisms (Anderson et al., 2018; Bai et al., 2021; Krause \& Hayward, 2015; Rudd et al., 2012; Sturm et al., 2020; Zhao et al., 2019). According to a previous study (Krause \& Hayward, 2015), our results showed that a sense of connection during positive awe experiences was positively correlated 
with well-being, which suggested that the feelings of connection to someone/thing (i.e., others and oneness) was associated with the effects of awe on well-being.

\section{Oppression}

We demonstrated that threat-awe induced greater feelings of oppression than positive awe and neutral emotional states, while positive awe did not induce greater feelings of oppression than neutral emotional states. Given that previous research suggested that threat-awe induced greater feelings of time pressure than positive awe (Guan et al., 2019), our results suggested that feelings of oppression in threat-awe experiences may have been associated with time perception. Further research should be conducted to investigate the effects of oppression in threat-awe experiences on cognition and behavior.

Interestingly, the results also revealed that individuals with high dispositional positive-awe tend to feel oppression after threat-awe experiences, which might be inconsistent with the previous research in Western cultures that have demonstrated that dispositional positive awe was not correlated with feelings of oppression induced awe experiences (Krenzer et al., 2020). Previous research has demonstrated that dispositional positive-awe was positively correlated with dispositional threat-awe among Japanese people but not among North Americans, suggesting that awe would be characterized as a more mixed emotion in Japan (Nakayama et al., 2020). Given that feelings of oppression are induced mainly by threat-awe experiences, the present research results provide us insights into awe as a mixed emotion in Japan in terms of dispositional awe and situational awe.

\section{Chills}

Consistent with previous research (Schurtz et al., 2012; Yaden et al., 2019), the present study demonstrated that both positive- and threat-awe experiences involved self-reported physiological responses. Previous research also demonstrated that awe experiences were associated with objective measures of psychophysiological responses such as goose bumps (Quesnel \& Riecke, 2018). Hence, it is of interest to investigate the relationships between the SAS-J chills subscale and such psychophysiological responses.

\section{Diminished self}

Our results showed that the two types of awe induced diminished self which was consistent with previous research (Gordon et al., 2017; Guan et al., 2019; Sawada \& Nomura, 2020;
Takano \& Nomura, 2020). Awe's diminished self effects have often been used as manipulation checks for the inductions of awe (Guan et al., 2019; Sawada \& Nomura, 2020; Takano \& Nomura, 2020, 2021). Since there were a small number of items of the SAS-J diminished self subscale, it would be useful for manipulation checks.

\section{Limitations and Future Research Directions}

Although the present study demonstrated that the SAS-J measures psychological states after awe experiences through three online surveys, it has some limitations. First, we did not investigate the relationship between the SAS-J and non-selfreported behavioral and objective physiological measures. As physiological responses are thought to be best measured by direct objective methods (Scherer \& Moors, 2019), previous research on awe has also used the direct objective methods (e.g., heart rate and skin conductance; Chirico et al., 2017; Gordon et al., 2017). In relation to this point, a previous study revealed that the SAS was associated with eye movements (rough-Jespersen et al., 2020). Further studies are required to examine whether and how the SAS-J is associated with behavioral, psychophysiological, and neuroscientific measures.

Second, we did not investigate whether the SAS-J measured awe experiences in the real world. Since we used video stimulus as a method of inducing awe based on previous research (e.g., Piff et al., 2015), the present study may lack ecological validity. As in a previous study (Krenzer et al., 2020), field experiments should be conducted to confirm the ecological validity of our results. Third, we only utilized nature as an awe-inducing stimulus, one of the most common elicitors of awe (Bai et al., 2017; Gordon et al., 2017). Relatively, we also focused only on threat among the "flavoring" features of awe (Keltner \& Haidt, 2003). It is of interest to examine whether the SAS-J would capture other "flavoring" features other than threats. For example, awe experiences involving a supernatural entity may be more closely associated with feelings of connection than awe experiences involving other "flavoring" features (Krause \& Hayward, 2015; van Cappellen \& Saroglou, 2012). Hence, future studies should examine whether and how the SAS-J would measure non-natural experiences of awe and capture other "flavoring" features of awe, combined with the AWE-S which can distinguish between awe in nature and interpersonal awe (Graziosi \& Yaden, 2021).

Additionally, we did not investigate the relationships between the SAS-J subscales and five well-being-related variables in Study 2 and 3. Interestingly, the results of Study 1 demonstrated that feelings of oppression after positive-awe experiences were negatively associated with four well-beingrelated variables other than searching for meaning in life. As threat-awe experiences mainly induce feelings of oppression, 
threat-awe might also decrease well-being compared with positive-awe in a Japanese sample. These indicate possibilities for future research.

\section{Conclusion}

The present study is the first to develop the Japanese version of the Situational Awe Scale (SAS-J) and confirms that it can measure psychological states after both positive- and threat-awe experiences. Developing the SAS-J has a methodological contribution to the study of awe. Previous research has suggested that the valence of awe was related to cultural differences in awe experiences (Nakayama et al., 2020; Nomura et al., 2022). Hence, the SAS-J, a measure of experiences of awe, including positive- and threat-awe, might be useful for cross-cultural research.

Supplementary Information The online version contains supplementary material available at https://doi.org/10.1007/s12144-022-02808-6.

Acknowledgements This work was supported partially by the Global Education Office, Graduate School of Education, Kyoto University.

Funding This work was supported by the Grants-in-Aid for Scientific Research (KAKENHI) (Grant No. $19 H 01773$ and 21J23196).

Data Availability The data and code that support the findings of this study are openly available at https://osf.io/ $9 \mathrm{e} 5 \mathrm{vc} /$.

\section{Declarations}

Ethics approval The present study was approved by the Ethical Review Board of Kyoto University (CPE-309).

Consent to participate All participants provided written informed consent.

Conflicts of Interest The authors declare no conflicts of interest.

Open Access This article is licensed under a Creative Commons Attribution 4.0 International License, which permits use, sharing, adaptation, distribution and reproduction in any medium or format, as long as you give appropriate credit to the original author(s) and the source, provide a link to the Creative Commons licence, and indicate if changes were made. The images or other third party material in this article are included in the article's Creative Commons licence, unless indicated otherwise in a credit line to the material. If material is not included in the article's Creative Commons licence and your intended use is not permitted by statutory regulation or exceeds the permitted use, you will need to obtain permission directly from the copyright holder. To view a copy of this licence, visit http://creativecommons.org/licenses/by/4.0/.

\section{References}

Anderson, C. L., Monroy, M., \& Keltner, D. (2018). Awe in nature heals: Evidence from military veterans, at-risk youth, and college students. Emotion, 18(8), 1195-1202. https://doi.org/ $10.1037 / \mathrm{emo} 0000442$

Bai, Y., Maruskin, L. A., Chen, S., Gordon, A. M., Stellar, J. E., McNeil, G. D., \& Keltner, D. (2017). Awe, the diminished self, and collective engagement: Universals and cultural variations in the small self. Journal of Personality and Social Psychology, 113, 185-209. https://doi.org/10.1037/pspa0000087

Bai, Y., Ocampo, J., Jin, G., Chen, S., Benet-Martinez, V., Monroy, M., ... \& Keltner, D. (2021). Awe, daily stress, and elevated life satisfaction. Journal of Personality and Social Psychology, 120(4), 837-860. https://doi.org/10.1037/pspa0000267.

Champely, S. (2020). pwr: Basic Functions for Power Analysis. R package version 1.3-0. https://cran.r-project.org/web/packages/ pwr/pwr.pdf

Chirico, A., Cipresso, P., Yaden, D. B., Biassoni, F., Riva, G., \& Gaggioli, A. (2017). Effectiveness of immersive videos in inducing awe: An Experimental Study. Scientific Reports, 7(1), 1218. https://doi.org/10.1038/s41598-017-01242-0

Diener, E., Emmons, R. A., Larsen, R. J., \& Griffin, S. (1985). The satisfaction with life scale. Journal of Personality Assessment, 49(1), 71-75. https://doi.org/10.1207/s15327752jpa4901_13

Gabriel, S., Naidu, E., Paravati, E., Morrison, C. D., \& Gainey, K. (2020). Creating the sacred from the profane: Collective effervescence and everyday activities. The Journal of Positive Psychology, 15(1), 129-154. https://doi.org/10.1080/17439760.2019.1689412

Gordon, A. M., Stellar, J. E., Anderson, C. L., McNeil, G. D., Loew, D., \& Keltner, D. (2017). The dark side of the sublime: Distinguishing a threat-based variant of awe. Journal of Personality and Social Psychology, 113(2), 310-328. https://doi.org/10.1037/ pspp0000120

Graziosi, M., \& Yaden, D. (2021). Interpersonal awe: Exploring the social domain of awe elicitors. The Journal of Positive Psychology, 16(2), 263-271. https://doi.org/10.1080/17439760.2019. 1689422

Guan, F., Chen, J., Chen, O., Liu, L., \& Zha, Y. (2019). Awe and prosocial tendency. Current Psychology, 1-9. https://doi.org/10. 1007/s12144-019-00244-7

Hitokoto, H., \& Uchida, Y. (2015). Interdependent happiness: Theoretical importance and measurement validity. Journal of Happiness Studies, 16(1), 211-239. https://doi.org/10.1007/ s10902-014-9505-8

Keltner, D., \& Haidt, J. (2003). Approaching awe, a moral, spiritual, and aesthetic emotion. Cognition and Emotion, 17(2), 297-314. https://doi.org/10.1080/02699930302297

Krause, N., \& Hayward, R. D. (2015). Assessing whether practical wisdom and awe of God are associated with life satisfaction. Psychology of Religion and Spirituality, 7(1), 51-59. https://doi.org/ 10.1037/a0037694

Krenzer, W. L. D., Krogh-Jespersen, S., Greenslit, J., Price, A., \& Quinn, K. A. (2020). Assessing the experience of awe: Validating the Situational Awe Scale. https://doi.org/10.31234/osf.io/dsytn.

Krogh-Jespersen, S., Quinn, K. A., Krenzer, W. L., Nguyen, C., Greenslit, J., \& Price, C. A. (2020). Exploring the awe-some: Mobile eye-tracking insights into awe in a science museum. PLoS ONE, 15(9), e0239204. https://doi.org/10.1371/journal.pone. 0239204

Lyubomirsky, S., \& Lepper, H. S. (1999). A measure of subjective happiness: Preliminary reliability and construct validation. Social Indicators Research, 46(2), 137-155. https://doi.org/10.1023/A: 1006824100041

McCullough, M. E., Emmons, R. A., \& Tsang, J. (2002). The grateful disposition: A conceptual and empirical topography. Journal of Personality and Social Psychology, 82(1), 112-127. https://doi. org/10.1037/0022-3514.82.1.112

Muto, S. (2014). The concept structure of respect-related emotions in Japanese university students. The Japanese Journal of 
Psychology, 85(2), 157-167. https://doi.org/10.4992/jjpsy.85. 13021

Nakayama, M., Nozaki, Y., Taylor, P. M., Keltner, D., \& Uchida, Y. (2020). Individual and cultural differences in predispositions to feel positive and negative aspects of awe. Journal of CrossCultural Psychology, 51(10), 771-793. https://doi.org/10.1177/ 2F0022022120959821

Nelson-Coffey, S. K., Ruberton, P. M., Chancellor, J., Cornick, J. E., Blascovich, J., \& Lyubomirsky, S. (2019). The proximal experience of awe. PLOS ONE, 14(5), e0216780. https://doi.org/10. 1371/journal.pone.0216780

Nomura, M. (2021). [Does "awe" induce aggressive behaviors?] "Ikeino-nen" ha kougekikoudou wo syouzuru no ka [in Japanese]? In Kamata, T (Eds.) Shinshinhenyou to iryou/hyougen $\sim$ kindai to dentou. JMA Management Center, pp. 304-313

Nomura, M., Tsuda, A., Rappleye, J. (2022). Defining awe in East Asia: Cultural differences in describing the emotion and experience of awe. In Chiao, J, Shu-Chen, Rebecca, Bob (eds.), Handbook of Cultural Neuroscience: Cultural Neuroscience and Health. New York: Oxford University Press. pp. 221-232

Piff, P. K., Dietze, P., Feinberg, M., Stancato, D. M., \& Keltner, D. (2015). Awe, the small self, and prosocial behavior. Journal of Personality and Social Psychology, 108(6), 883-899. https://doi. org/10.1037/pspi0000018

Price, C. A., Greenslit, J. N., Applebaum, L., Harris, N., Segovia, G., Quinn, K. A., \& Krogh-Jespersen, S. (2021). Awe \& Memories of Learning in Science and Art Museums. Visitor Studies, 1-50. https://doi.org/10.1080/10645578.2021.1907152

Quesnel, D., \& Riecke, B. E. (2018). Are you awed yet? How virtual reality gives us awe and goose bumps. Frontiers in Psychology, 9, 2158. https://doi.org/10.3389/fpsyg.2018.02158

Razavi, P., Zhang, J. W., Hekiert, D., Yoo, S. H., \& Howell, R. T. (2016). Cross-cultural similarities and differences in the experience of awe. Emotion, 16(8), 1097-1101. https://doi.org/10.1037/ emo0000225

R Core Team (2021). R: A language and environment for statistical computing. R Foundation for Statistical Computing, Vienna, Austria. https://www.R-project.org/

Robitzsch, A., \& Grund, S. (2021). miceadds: Some Additional Multiple Imputation Functions, Especially for 'mice'. R package version 3.11-6. https://CRAN.R-project.org/package=miceadds

Rosseel, Y. (2012). Lavaan: An R package for structural equation modeling and more. Version 0.5-12 (BETA). Journal of Statistical Software, 48(2), 1-36.

Rudd, M., Vohs, K. D., \& Aaker, J. (2012). Awe expands people's perception of time, alters decision making, and enhances wellbeing. Psychological Science, 23, 1130-1136. https://doi.org/10. 1177/2F0956797612438731

Sawada, K., \& Nomura, M. (2020). Influence of two types of awe on attitude toward norm violation. Frontiers in Psychology, 11, 148. https://doi.org/10.3389/fpsyg.2020.00148

Scherer, K. R., \& Moors, A. (2019). The emotion process: Event appraisal and component differentiation. Annual Review of Psychology, 70, 719-745. https://doi.org/10.1146/annur ev-psych-122216-011854

Schurtz, D. R., Blincoe, S., Smith, R. H., Powell, C. A., Combs, D. J., \& Kim, S. H. (2012). Exploring the social aspects of goose bumps and their role in awe and envy. Motivation and Emotion, 36(2), 205-217. https://doi.org/10.1007/s11031-011-9243-8

Shimai, S., Otake, K., Utsuki, N., Ikemi, A., \& Lyubomirsky, S. (2004). Development of a Japanese version of the subjective happiness scale (SHS), and examination of its validity and reliability. Japanese Journal of Public Health, 51(10), 845-853.

Shimai, S., Arimitsu, K., \& Steger, M. F. (2019). Meaning in life across developmental stages among Japanese adults: Scores and correlates. Journal of Health Psychology Research, 32(1), 1-10. https:// doi.org/10.11560/jhpr.181206118

Shiota, M. N., Keltner, D., \& John, O. P. (2006). Positive emotion dispositions differentially associated with Big Five personality and attachment style. The Journal of Positive Psychology, 1, 61-71. https://doi.org/10.1080/17439760500510833

Shiota, M. N., Keltner, D., \& Mossman, A. (2007). The nature of awe: Elicitors, appraisals, and effects on self-concept. Cognition and Emotion, 21, 944-963. https://doi.org/10.1080/026999306009236 68

Shiraki, Y., \& Igarashi, T. (2014). Development of the Japanese of the trait gratitude scale. Japanese Journal of Interpersonal and Social Psychology, 14, 27-33.

Steger, M. F., Frazier, P., Oishi, S., \& Kaler, M. (2006). The meaning in life questionnaire: Assessing the presence of and search for meaning in life. Journal of Counseling Psychology, 53(1), 80-93. https://doi.org/10.1037/0022-0167.53.1.80

Stellar, J. E., Gordon, A. M., Piff, P. K., Cordaro, D., Anderson, C. L., Bai, Y., ... Keltner, D. (2017). Self-Transcendent Emotions and Their Social Functions: Compassion, Gratitude, and Awe Bind Us to Others Through Prosociality. Emotion Review, 9(3), 200-207. https://doi.org/10.1177/1754073916684557.

Stellar, J. E., Gordon, A., Anderson, C. L., Piff, P. K., McNeil, G. D., \& Keltner, D. (2018). Awe and humility. Journal of Personality and Social Psychology, 114(2), 258-269. https://doi.org/10.1037/ pspi0000109

Sturm, V. E., Datta, S., Roy, A. R., Sible, I. J., Kosik, E. L., Veziris, C. R., ... \& Keltner, D. (2020). Big smile, small self: Awe walks promote prosocial positive emotions in older adults. Emotion. Advance online publication. https://doi.org/10.1037/emo0000876.

Takano, R., \& Nomura, M. (2020). Neural representations of awe: Distinguishing common and distinct neural mechanisms. Emotion. Advance online publication. https://doi.org/10.1037/emo0000771.

Takano, R., \& Nomura, M. (2021). Awe liberates the feeling that "my body is mine." Cognition and Emotion, 35(4), 738-744. https:// doi.org/10.1080/02699931.2020.1862765

Uchida, Y., \& Kitayama, S. (2009). Happiness and unhappiness in east and west: Themes and variations. Emotion, 9(4), 441. https://doi. org/10.1037/a0015634

Van Cappellen, P., \& Saroglou, V. (2012). Awe activates religious and spiritual feelings and behavioral intentions. Psychology of Religion and Spirituality, 4(3), 223-236. https://doi.org/10.1037/ a0025986

Yaden, D. B., Kaufman, S. B., Hyde, E., Chirico, A., Gaggioli, A., Zhang, J. W., \& Keltner, D. (2019). The development of the Awe Experience Scale (AWE-S): A multifactorial measure for a complex emotion. The Journal of Positive Psychology, 14(4), 474-488. https://doi.org/10.1080/17439760.2018.1484940

Zhao, H., Zhang, H., Xu, Y., He, W., \& Lu, J. (2019). Why Are People High in Dispositional Awe Happier? The Roles of Meaning in Life and Materialism. Frontiers in Psychology, 10, 1208. https://doi. org/10.3389/fpsyg.2019.01208

Publisher's Note Springer Nature remains neutral with regard to jurisdictional claims in published maps and institutional affiliations. 